\title{
Nail clubbing in laxative abuse: case report and review of the literature
}

\author{
Olivia A. Charlton ${ }^{1 *}$ (D, Philippa Dickison ${ }^{1}$, Saxon D. Smith ${ }^{1,2}$ and Simon D. Roger ${ }^{3}$
}

\begin{abstract}
Background: The link between clubbing and laxative abuse has been reported several times in the literature, in all cases in young females. The nature of this relationship is not understood.

Case: A young female, with no history of hepatic, pulmonary or malignant disease was found to have nail clubbing in the context of laxative abuse. A literature review revealed several similar cases.

Conclusion: Laxative abuse is an important consideration in the assessment of clubbing in populations at risk of eating disorders, to prevent over-investigation and facilitate management of the eating disorder itself. This case highlights a new clinical presentation of an eating disorder.

Case: A 36-year-old woman was being reviewed by a renal specialist for renal impairment and electrolyte disturbances, in the context of a background of multiple renal calculi 4 years prior, hypokalaemia and hypercalcaemia. The attending nephrologist brought attention to her nails, which demonstrated clubbing. She stated that she had had clubbing for 10 years, and that it was of gradual onset and not associated with any pain. There was no history of hepatic, cardoipulmonary or malignant disease.
\end{abstract}

Keywords: Eating disorder, Clubbing, Nail clubbing, Laxative abuse

The patient also had a background of gastrointestinal reflux disease, depression, anxiety and an eating disorder. Her current medications included: mirtazapine, olanzapine, quetiapine, temazepam, antacid, pantoprazole and potassium supplements. She was also taking at least 15 tablets of either senna or docusate sodium (Coloxyl) and senna on a daily basis. She further reported taking 90 to 100 senna tablets at the peak of her eating disorder 4 years prior, at which point she weight $28 \mathrm{~kg}$.

On examination, the patient was found to have bilateral clubbing of all finger nails (Fig. 1). She was underweight, weighing $41.7 \mathrm{~kg}$; her body mass index (BMI) was 16.8. The rest of the examination was normal. Investigations demonstrated chronic renal disease (creatinine $130 \mu \mathrm{mol} / \mathrm{L})$, hypercalaemia $(2.8 \mathrm{mmol} / \mathrm{L})$, hypokalaemia $(3.1 \mathrm{mmol} / \mathrm{L})$ and low vitamin $\mathrm{D}(12 \mathrm{nmol} / \mathrm{L})$. Her renal biopsy demonstrated a significantly thickened glomerular basement membrane and acute tubular injury, however there was no clear diagnosis. A computed tomography $(\mathrm{CT})$ scan did not reveal any underlying malignancy, and an echocardiogram did not indicate a cardiac cause for the nail clubbing.

The absence of symptoms, previous history, and investigation results indicated that the most likely cause of her finger clubbing was her use of senna. Unfortunately this patient has continued daily use of laxatives, in spite of repeated recommendations that she cease using them, and the clubbing has not resolved.

\section{Discussion and conclusions}

Finger clubbing has been associated with cardiac, pulmonary, neoplastic and gastrointestinal diseases or infections [1]. It is also part of the syndrome of primary or secondary hypertrophic osteoarthropathy (HOA). HOA is characterised by periostosis of long bones, joint pain and clubbing [1].

The pathophysiology underlying the development of clubbing is not entirely understood. The proposed

\footnotetext{
* Correspondence: oacharlton@gmail.com

'Department of Dermatology, Royal North Shore Hospital, Sydney

0419125257, Australia

Full list of author information is available at the end of the article
}

(c) The Author(s). 2019 Open Access This article is distributed under the terms of the Creative Commons Attribution 4.0 International License (http://creativecommons.org/licenses/by/4.0/), which permits unrestricted use, distribution, and reproduction in any medium, provided you give appropriate credit to the original author(s) and the source, provide a link to the Creative Commons license, and indicate if changes were made. The Creative Commons Public Domain Dedication waiver (http://creativecommons.org/publicdomain/zero/1.0/) applies to the data made available in this article, unless otherwise stated. 


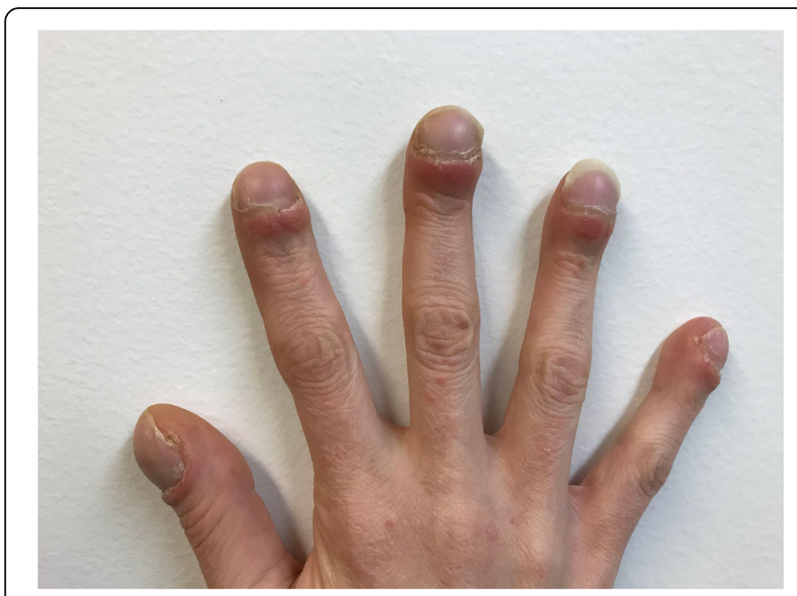

Fig. 1 The tips of the fingers are enlarged, and the nails curve around the fingertips

mechanisms relate to altered vascular dynamics and vasodilation in the fingers; increased production of plasma growth hormone; and increased concentration of megakaryocytes impacting in the fingertip circulation [1]. None of the theories explaining the development of clubbing encompasses all associations.

An example of an unexplained association with clubbing is laxative abuse. This link has been reported several times in the literature since Silk et al. [2] in 1975 (Table 1). Like this case, all the cases were females who admitted to consuming high amounts of senna tablets to control their weight. In 3 cases, the link was established or confirmed after senna derivatives were identified in the urine [2-4]. Similarly, many of the previously reported cases had associated hypokalaemia, chronic renal failure or fluid retention. Additionally, one report also linked a patient's hypercalcaemia to the calcium in senna tablets $(12.5 \mathrm{mg}$ calcium per senna tablet) [5].

The link between laxative abuse, specifically senna, and clubbing is unknown. It has been postulated to be related to diarrhoea or malnutrition $[6,7]$. Importantly, the diagnosis can only be established after pulmonary, cardiac, neoplastic and gastrointestinal causes are excluded. Interestingly the clubbing was reported to resolve upon cessation of senna $[2,8,9]$.

\section{Conclusion}

This case adds to the increasing, though small, number of reports linking senna and finger clubbing. It is important to consider laxative abuse in cases of clubbing, especially in young, underweight female patients. Awareness of this association may prevent over-investigation and facilitate the diagnosis and management of an eating disorder.

Table 1 Case reports which have identified clubbing in patients consuming laxatives

\begin{tabular}{|c|c|c|c|c|}
\hline Manuscript & $\begin{array}{l}\text { Patient } \\
\text { details }\end{array}$ & Associated & Laxative & FU \\
\hline $\begin{array}{l}\text { Silk et al. } \\
(1975)[2]\end{array}$ & 26уо F & $\begin{array}{l}\text { History of persisting vomiting } \\
\text { Normal UECs }\end{array}$ & $\begin{array}{l}\text { 100-200 Senna tablets/ } \\
\text { day }\end{array}$ & Resolved with cessation of aperients \\
\hline $\begin{array}{l}\text { Prior and White } \\
\text { (1978) [4] }\end{array}$ & 24yo F & $\begin{array}{l}\text { Hyperventilation leading to } \\
\text { tetany } \\
\text { Hypokalaemia }\end{array}$ & 50 Senna tablets/day & Continued laxative use and clubbing \\
\hline $\begin{array}{l}\text { Malmquist et al. } \\
\text { (1980) [8] }\end{array}$ & $\begin{array}{l}30 \text { yo F } \\
48 \mathrm{~kg}\end{array}$ & $\begin{array}{l}\text { Aspartylglucosaminuria } \\
\text { Radius bones curved } \\
\text { Fluctuating fluid retention }\end{array}$ & Pursennid (Senna) & Continued laxative use and clubbing \\
\hline $\begin{array}{l}\text { Levine et al. } \\
\text { (1981) [6] }\end{array}$ & $\begin{array}{l}65 \mathrm{yo} \mathrm{F} \\
24 \mathrm{~kg}\end{array}$ & $\begin{array}{l}\text { Hypokalaemia } \\
\text { Hypoalbuminaemia }\end{array}$ & Senna & Resolution with cessation of senna \\
\hline $\begin{array}{l}\text { Armstrong et al. } \\
\text { (1981) [9] }\end{array}$ & 21 yo $\mathrm{F}$ & $\mathrm{HOA}$ & > 3 Senna tablets/day & Resolution within 6 months of ceasing senna \\
\hline $\begin{array}{l}\text { Fitzgerald \& Redmond } \\
\text { (1983) [7] }\end{array}$ & 44 yo F & $\begin{array}{l}\text { Hypokalaemia } \\
\text { Paranoid schizophrenia }\end{array}$ & 4-40 Senna tablets/day & Changed to Bisacodyl; clubbing "regressing" \\
\hline \multirow[t]{2}{*}{$\begin{array}{l}\text { Pines et al. } \\
\text { (1983) [10] }\end{array}$} & $\begin{array}{l}28 y o ~ F \\
43 \mathrm{~kg}\end{array}$ & Hypokalaemia & 20-30 Senna tablets/day & Continued clubbing and laxative use \\
\hline & $\begin{array}{l}35 y o \mathrm{~F} \\
46 \mathrm{~kg}\end{array}$ & $\begin{array}{l}\text { IDDM } \\
\text { Smoker }\end{array}$ & $\begin{array}{l}\text { Paraffin oil } \\
\text { Senna }\end{array}$ & Continued clubbing and laxative use \\
\hline $\begin{array}{l}\text { Currie et al. } \\
\text { (2007) [3] }\end{array}$ & 62 yo F & $\begin{array}{l}\text { Mild chronic renal failure } \\
\text { Hypokalaemia }\end{array}$ & $\begin{array}{l}\text { Senna } \\
\text { Lactulose }\end{array}$ & Continued clubbing and laxative use \\
\hline $\begin{array}{l}\text { Lim, Hooke and } \\
\text { Kerr (2008) [5] }\end{array}$ & $\begin{array}{l}36 y o ~ F \\
\text { BMI } 17.7\end{array}$ & $\begin{array}{l}\text { Smoker } \\
\text { Hypercalcaemia } \\
\text { Hypokalaemia } \\
\text { Fluid retention } \\
\text { HOA* }^{*}\end{array}$ & 50-100 Senna tablets/day & $\begin{array}{l}\text { Persistent despite reported reduction in } \\
\text { Senna }\end{array}$ \\
\hline
\end{tabular}




\section{Abbreviations}

BMI: Body mass index; CT: Computed tomography; HOA: Hypertrophic osteoarthropathy

\section{Acknowledgements}

None.

This paper is original work and has not been published, or submitted for publication elsewhere.

\section{Funding}

There is no funding to declare.

\section{Availability of data and materials}

All authors had access to the relevant material in the generation and review of this manuscript.

\section{Authors' contributions}

Each author has contributed significantly to the work and is in agreement regarding the findings. All authors read and approved the final manuscript.

\section{Ethics approval and consent to participate}

Due to the nature of this case report, ethics approval was not necessary.

\section{Consent for publication}

Informed written consent was obtained from the patient for use of clinical images, history and publication of this case report.

\section{Competing interests}

The authors declare that they have no competing interests.

\section{Publisher's Note}

Springer Nature remains neutral with regard to jurisdictional claims in published maps and institutional affiliations.

\section{Author details}

'Department of Dermatology, Royal North Shore Hospital, Sydney 0419125257, Australia. ${ }^{2}$ The Dermatology and Skin Cancer Centre, Gosford, Australia. ${ }^{3}$ Department of Renal medicine, Gosford Hospital, Gosford, Australia.

Received: 29 December 2018 Accepted: 14 February 2019

Published online: 05 March 2019

\section{References}

1. Spicknall KE, Zirwas MJ, English JC, 3rd. Clubbing: an update on diagnosis, differential diagnosis, pathophysiology, and clinical relevance. J Am Acad Dermatol 2005;52(6):1020-1028

2. Silk DB, Gibson JA, Murray CR. Reversible finger clubbing in a case of purgative abuse. Gastroenterology. 1975;68(4 Pt 1):790-4.

3. Currie GP, Niruban A, Dempsey OJ. A rare cause of finger clubbing in a lifelong nonsmoker. Br J Clin Pharmacol. 2007;63(2):252.

4. Prior J, White I. Tetany and clubbing in patient who ingested large quantities of senna. Lancet. 1978;2(8096):947.

5. Lim AK, Hooke DH, Kerr PG. Anorexia nervosa and senna misuse: nephrocalcinosis, digital clubbing and hypertrophic osteoarthropathy. Med J Aust. 2008;188(2):121-2.

6. Levine D, Goode AW, Wingate DL. Purgative abuse associated with reversible cachexia, hypogammaglobulinaemia, and finger clubbing. Lancet. 1981:1(8226):919-20.

7. FitzGerald O, Redmond J. Anthraquinone-induced clubbing associated with laxative abuse. Ir J Med Sci. 1983:152(6):246-7.

8. Malmquist J, Ericsson B, Hulten-Nosslin MB, Jeppsson JO, Ljungberg O Finger clubbing and aspartylglucosamine excretion in a laxative-abusing patient. Postgrad Med J. 1980;56(662):862-4.

9. Armstrong RD, Crisp AJ, Grahame R, Woolf DL. Hypertrophic osteoarthropathy and purgative abuse. Br Med J (Clin Res Ed). 1981:282(6279):1836.

10. Pines A, Olchovsky D, Bregman J, Kaplinsky N, Frankl O. Finger clubbing associated with laxative abuse. South Med J. 1983:76(8):1071-2.

11. McLaughlin AF. Anorexia nervosa and senna misuse: nephrocalcinosis, digital clubbing and hypertrophic osteoarthropathy. Med J Aust. 2008 189(6):348.

Ready to submit your research? Choose BMC and benefit from:

- fast, convenient online submission

- thorough peer review by experienced researchers in your field

- rapid publication on acceptance

- support for research data, including large and complex data types

- gold Open Access which fosters wider collaboration and increased citations

- maximum visibility for your research: over $100 \mathrm{M}$ website views per year

At $\mathrm{BMC}$, research is always in progress.

Learn more biomedcentral.com/submissions 